\title{
Migration and Uncertainties \\ The Ordeal of Syrian Women Refugees with Missing Spouses
}

\author{
Hakan Gülerce
}

The ongoing civil war in Syria has caused millions of people to migrate across the border in order to save their lives. However, as they reached on safer grounds, they were left homeless. This migration has been occurring intensively to countries with borders neighboring Syria. Turkey has the highest number of refugees among Syria's neighboring countries, harboring close to four million Syrian refugees. There are only a small proportion of the Syrian refugee population living in temporary accommodation centers as the larger part is scattered throughout the various provinces of Turkey. Although they encounter certain problems that relate to different provinces, most of the troubles experienced by the refugees are common to all of them.

Among the cities with dense Syrian refugee population, Şanlıurfa stands out as the fourth city after Istanbul, Gaziantep and Hatay with 420,779 asylum seekers as of 2020 (General Directorate of Migration Management, 2020). Although in the beginning the Syrian refugees were characterized as "temporary guests," the protraction of the civil war along with an assessment of residence time in Turkey has caused them to stay in Turkey for a more prolonged period or most probably it will be permanently. Accordingly, new policies for the development of practical coexistence between refugees and locals have become more of an issue.

Dr. Öğr. Üyesi, Harran Üniversitesi. hakangulerce@harran.edu.tr

(iD) http://orcid.org/0000-0003-3601-5725

(C) İlmi Etüdler Derneği 
Women and children, the most fragile actors in migration, make up the bulk of the displaced. In this case study analysis, the problem of missing relatives, one of the common grievances of women asylum seekers, was examined through the case of Aisha (not her real name), a Syrian woman refugee living in Şanlıurfa. Thus, the aim is to determine the content of one of the main challenges faced by refugee women encountered in the field and to establish a reference point for further detailed research in this field. At the same time, the results from this case study analysis will be a guide for decision makers and compliance studies.

It is very difficult for people who have escaped from a war environment, with some of their relatives and family members killed, to adapt to a new life in a new society. The main difficulties are the uncertainties experienced by refugees in many issues. These uncertainties are one of the obstacles to the development of a culture of coexistence among Syrian refugees and local communities. For example, it is unclear how long the refugees will remain in Turkey. However, the perspective that the 'temporary guest' is transient precludes the forging of permanent and comprehensive solutions. Bauman (2018) cites Michel Agier's (2002) concept of "liminal drift" in one of his works. According to Agier, refugees "have been cast in a condition of 'liminal drift', with no way of knowing whether it is transitory or permanent. Even if they are stationary for a time, they are on a journey that is never completed since its destination (arrival or return) remains forever unclear, while a place they could call 'final' remains forever inaccessible. They are never to be free from the gnawing sense of the transience, indefiniteness and provisional nature of any settlement." (Bauman, 2018, p. 92). On this basis, it can be stated that the psychosocial problems experienced by refugees are directly proportional to the state of uncertainty that they face. This is closely related to both the resilience of refugee individuals and the ability to survive in the community in which they live.

In this case study analysis, the basis is the intermediate findings of the research named "Migration and Processes: The Example of Syrian Families in Şanlıurfa" on the social inclusion and integration process of Syrian refugee families in Şanlıurfa and the results of which have not yet been published. This research subsuming indepth interviews with 12 different families (mother or father) living in Şanlıurfa has tried to understand the refugees' problems of experience and integration, refugee networks in Şanlıurfa, refugees' intentions regarding the future intentions and their expectations. This study will include the statements of Aisha, the mother of four daughters, who was interviewed within the scope of the research, about the difficulties caused by the ambiguity related to the fate of her missing husband. 
Aisha's twin children are 4 years old and the other two daughters are 6 and 8 years old. Aisha states that her husband has disappeared in Syria. The inner state of Aisha, who has not been able to hear from her husband for three years, has had a serious impact on the adaptation process of her new life in Şanliurfa. The experiences of Aisha who has sought refuge in Turkey due to internal turmoil in Syria indicates a major social problem in the context of social cohesion. This case study analysis aims to draw attention to Syrian refugee women who have lost their spouses, a problem having many social, psychological and legal dimensions that have not yet been adequately addressed in migration studies and the administrative field.

The cause for migration by refugee women in Turkey is mainly the civil war in Syria. In this context, when asked in the study the reason why she migrated to Turkey, the refugee Aisha replied:

I migrated to Turkey because of the war. In the war, I lost my whole family (parents and siblings). I don't know if my husband is still alive. I heard from some people that he died. I have no idea where my husband is. The decision to migrate to Turkey was taken suddenly. My children and I left the city because of the war. At that moment I thought of only one thing. I lost my family and my husband, but I can't afford to lose my children. I was always living with this fear in me, so I wanted to leave the city where I was. I settled in a camp inside Syria.

One of the most important problems faced by Syrian women are those experienced in the migration journey to Turkey. The migration journey of women brings with it another uncertainty. They do not know what they will encounter during the journey. For example, in this journey they lose almost all of their material savings. Especially women migrating illegally are obliged to hand over the money in their possession to human traffickers. Aisha's migration story is an example of this:

I talked to a smuggler right from the moment I made the decision. I had some gold with me. He agreed when I mentioned about the amount. He said when he calls me I need to come. I prepared my children and myself. He called me and I went to his location. There were only women and their children in the place. He hid us inside a big truck. We were very scared. We stayed in the truck's crate for quite a long time. He slipped us through several villages. Then we got off and stayed in a village for a short time. We were filled with fear every single moment. Then we got on the truck again. We got off after a while. He said that we would cross the border through wire fences. We walked for a long time to the border. When we arrived, he took the gold from me and the women who were with me also gave their gold and money to him. As soon as he got the money and gold, he left us. We started to go through the wire fences. My hand was injured and another child in our group was injured. The smuggler was a very evil person. We did not know how and where we would go after we crossed the border. We started walking, we got 
very tired, and then we came across a main road. But we didn't know where to go. A man appeared before us. We are very happy. He brought us to Sanliurfa.

Aisha, entered from Syria to Turkey using illegal means. After a while, she and her four children applied to the Şanlıurfa Governorate Provincial Directorate of Migration Management and were taken under temporary protection. However, it is written in Aisha's temporary protection identity document that she is married as during the registration she was unable to present any documents that her husband was missing or dead. Therefore, Aisha seems officially married, but no contact with her husband can be established. Aisha said, "Am I a widow, am I married?" and expressed the problems she experienced as follows:

\begin{abstract}
Myself and women like me have not seen our spouses die. I do not have any documents or evidence that my husband is dead. I just hear different things. Some people say he's dead, while others say no, he could be a prisoner. This situation is very, very painful for me. Am I a widow, a divorced woman, or am I still married? This situation is not clear. I have no information about my husband. I can't build a new life right now. For example, I can't get married. If I apply for help to any association, they want a document that proves that my husband is dead so they can help me further. At the moment in Syria, due to the war they do not issue a death certificate for anyone. If they don't have a death certificate, they want me to take an oath that my husband is dead. I can't take an oath on this. I didn't see my husband die. Let's say my husband lives, I hope that is so, how do I get along with four children?
\end{abstract}

As can be seen in the example of Aisha, asylum-seeking women who try to adapt to their new life after forced migration across borders and who do not get news regarding their missing spouses experience various troubles due to the uncertainties and the difficulties this situation brings. It is obvious that the issue is not an exceptional situation limited only to Aisha. It is estimated that there are hundreds of women in the same situation. Therefore, the social, psychological and legal aspects of this question should be handled with detailed research and put forward in detail. Based on the results of these studies, decision-makers should produce new policies for the solution of problems and create sustainable solutions with reforms. New projects should be produced relating the field experience of civil society and the academic knowledge of universities with a delicate approach that will reach the refugees and has regard for human anxiety thresholds. This is because the attainment of such a dynamism and the bi-directional development of the integration and social cohesion process is of great importance in terms of protecting from many, if not all, possible risks, and developing strategies that are flexible. 


\section{References}

Bauman, Z. (2018). Iskarta hayatlar modernite ve safraları. İstanbul: Can Sanat Yayınları.

Agier, M. (2002). Aux bords du monde, les refugies. Flammarion.

Göç İdaresi Genel Müdürlüğü. (2020). Geçici koruma. https://www.goc.gov.tr/gecici-koruma5638 adresinden 28.06.2020 tarihinde erişilmiştir. 